\title{
ArcheoSciences
}

Revue d'archéométrie

\section{Funeral golden mask and hand with a ring. The necropolis of Trebeniste}

Le masque funéraire en or et la main baguée - la nécropole de Trebeniste

\section{Pavlina Ilieva and Petia Penkova}

\section{(2) OpenEdition}

1 Journals

Electronic version

URL: https://journals.openedition.org/archeosciences/2203

DOI: 10.4000/archeosciences.2203

ISBN: 978-2-7535-1598-7

ISSN: $2104-3728$

Publisher

Presses universitaires de Rennes

\section{Printed version}

Date of publication: 31 December 2009

ISBN: 978-2-7535-1181-1

ISSN: 1960-1360

\section{Electronic reference}

Pavlina Ilieva and Petia Penkova, "Funeral golden mask and hand with a ring. The necropolis of Trebeniste", ArcheoSciences [Online], 33 | 2009, Online since 10 December 2012, connection on 31 January 2022. URL: http://journals.openedition.org/archeosciences/2203 ; DOI: https://doi.org/ 10.4000/archeosciences.2203 


\title{
Funeral golden mask and hand with a ring The necropolis of Trebeniste
}

\author{
Le masque funéraire en or et la main baguée - la nécropole de Trebeniste
}

\author{
Pavlina Illeva* and Petia Penkova**
}

\begin{abstract}
This study reviews the historical background of the Necropolis of Trebeniste while also highlighting some of the main hypotheses that help date this site and explain its significance. Furthermore, it provides a description of the tombs and focuses on two of the golden objects excavated from the graves - a funeral golden mask and a hand with a ring. It lays out the results of an analysis of the crafting techniques used - one that was conducted at a laboratory of the National Archaeological Institute with Museum under the Bulgarian Academy of Sciences in Sofia, Bulgaria. This analysis aims to contribute to the further investigation and argumentation pertaining to the dating of these findings. It also hopes to suggest potential new areas of research.

Résumé : Cette étude fait un bilan du contexte historique de la Nécropole de Trebeniste et souligne quelques unes des hypothèses qui contribuent à la datation de ce site et qui expliquent sa signification. En outre, ce travail fourni une description des tombes et se concentre sur deux objets en or fouillés dans les tombeaux - un masque funéraire et une main avec une bageue. Cette étude expose brièvement les résultats d'une analyse des techniques artisanales utilisées - une qui a été menée au laboratoire de l'Institut national d'Archéologie avec Musée, de l'Académie Bulgare de Sciences, à Sofia. Cette analyse a pour but de contribuer aux recherches et argumentations se rapportant à la datation de ces découvertes. Ce travail prétend aussi suggérer de nouveaux domaines potentiels de recherche.
\end{abstract}

Keywords: Trebeniste, funeral mask, hand with ring, techniques.

Mots-clés : Trebeniste, masque funéraire, main avec bague, techniques.

\section{INTRODUCTION}

Ninety years ago, nearby Lake Ohrid, the seven graves of Trebeniste were excavated. The necropolis was discovered by accident in 1918 by a Bulgarian military unit mending roads in the region. The First World War hindered archaeologists Bogdan Filov and Carel Shkorpil from publishing material about these finds before 1927 (Filov and Schkorpil, 1927). In the past, the Trebeniste region was renowned for its rich silver bed - the silver mines of Damastius mentioned by Strabo were nearby. The most important Balkan roads used to intersect there as well, stretching in all four directions of the world. Three and a half kilometres west of Lake Ohrid lies a plain crossed by the Drin river. The mountains of present day Albania separate this area from the Adriatic Sea. Two rivers, Shkumbin (Genesis) and Semeni (Aspus), connect this land to the shore.

* Head of Collections Department, National Archaeological Institute with Museum, Sofia, Bulgarian Academy of Sciences - 2, Saborna str., Sofia 1000, Bulgaria. (polly_ilieva@mail.bg)

** Head of the Laboratory of Analysis, Conservation and Restoration, National Archaeological Institute with Museum, Bulgarian Academy of Sciences -2, Saborna str., Sofia 1000, Bulgaria. (petiapenkova@yahoo.com) 
Early Greek influences had an impact on this area during the period of Greek colonization, when the fist historic contacts started to take place. In the $7^{\text {th }}$ century BC, the Greeks started building a network of apoikoi spreading out across the Adriatic Sea and based on powerful settlements such as Korkyra (present day island of Corfu), Epidamnus (Dirahium, present day Duresu) and Apolonia (present day Pozhan). Korkyra was the first Greek colony in the Adriatic: it was used by the Greek colonizers as a support base for penetration further north. Sea access was under the control of the colony in Korkyra: its propitious geographic location turned it into an important centre for Greek colonization. A very similar picture can be drawn regarding the shores of the Black Sea and the Aegean Sea. These developments are usually considered evidence supporting the hypothesis that a significant number of items excavated from the Trebeniste necropolis were imported from Greece, while others are considered to be of Thracian-barbarian origin with Greek influences. Since a significant chronological gap of eight centuries exists between the end of the Mycenaean civilization and the golden days of Classical Thrace, we could also accept interpretations of some items of Thracian material culture from the Classic and early Hellenistic period as being 'reminiscent of the Aegean'. There is, however, strong evidence which documents the relocation of the Aegean civilization to the north - north-east, and the Trebeniste necropolis can thus be viewed as an intermediary link between the Thracian and Mycenaean civilizations.

Studies of the necropolis show a prolonged period of existence - from the $7^{\text {th }}$ century BC to the end of the $4^{\text {th }}$ and the beginning of the $3^{\text {rd }}$ century BC. The Trebeniste necropolis is dated back to a period between the $7^{\text {th }}$ century $\mathrm{BC}$ and $300 \mathrm{BC}$. A rich funeral inventory is only found in tombs dated towards the end of the $6^{\text {th }}$ century BC. This fact confirms the thesis regarding the presence of lavish 'imported' vessels, goblets and silver rhytons - only to be found in the tombs of 'kings'. Written sources about Thrace, Skythia, Macedonia, and Asia Minor interpret these objects as royal insignias (Popovic, 1994). Certain graves of men, women and children, dated back to the late $6^{\text {th }}$ century BC, contain notably rich grave goods, treasured today in three states Bulgaria (in Sofia), Serbia (in Belgrade), and Macedonia (in Ohrid). The graves are pits with floors of trampled down earth and fillings of soil mixed with big stones (Vulic, 1933). Warriors have been buried there, in ceremonial attire, with their arms, vessels and other belongings.

Thin golden lamellae (bratteae) in the shape of embroidery and rosettes beautified gorgeous mantles made probably of multicoloured fabrics. Elegant silver or silver gilt pins fastened the mantles (Stibbe, 1994). Golden bands also deco- rated the helmets, cuirasses, shields and swords. A golden band has been fastened above the forehead of a helmet, or runs along the entire front of another piece. The golden lamella shaped as a crescent, and the bronze ones representing horses were once probably fastened upon the breastplate of a cuirass and the leather overall of a shield. A golden rosette also decorated the sword scabbard from grave no. 7 . The funeral golden masks, a hand with a ring, and a sandal made of a thin sheet of gold, found in three graves, reflect the high social status of the warriors (the graves are dated to a period around the end of the $6^{\text {th }}$ century BC), and their particular role as heralds of the ideology and traditions of the society they belonged to. Beads of amber and glass, and numerous vessels made of silver, bronze, glass or clay are also found among the offerings.

\section{ANalytical eQuipMent}

A digital microscope by Keyence has been used for the observation of the production technology. The magnification range is $25 \mathrm{x}-175 \mathrm{x}$.

The XRF instrument used is model EDX-720 of Shimadzu; Atmosphere: Air; Collimator: $1 \mathrm{~mm}$.

\begin{tabular}{|c|c|c|c|c|c|}
\hline Analyte & TG & kV & uA & Acq. (keV) & Anal. (keV) \\
\hline Ti-U & Rh & 50 & Auto & $0-40$ & $0.00-40.00$ \\
\hline Na-Sc & Rh & 15 & Auto & $0-20$ & $0.00-4.40$ \\
\hline
\end{tabular}

The calculation method is Quan-FP (fundamental parameters). The detection limit was $0.01 \%$, but varies for the different elements. The analyser automatically detects statistical data concerning the presence or absence of elements around the detection limit. The lack of standard samples and the fact that no preliminary treatment was carried out on the surface renders the interpretation of the results as semi-quantitative. Despite the limitations of the method, the presence or absence of an element is a valid finding.

\section{Results AND DISCUSSION}

Mask: a focus on the technology used in crafting the mask allowed us to trace the sequence and types of techniques that were involved in this process. We can infer that, initially, the craftsperson cut out a thin golden sheet - estimated to be about $0.03 \mathrm{~mm}$ in width and approximately the size of a human face. If we assume that the mask was crafted especially for the person buried with it, then its size was 
most probably measured accordingly. It is also possible that it was even laid out on this person's face in order to obtain correct measurements of the exact location of the eyes, nose and lips. The nose is depicted by an aperture - most likely to avoid a potential rupture of the thin golden sheet that a high relief can cause. The nose - crafted separately - and the entire mask were both punctured with eight holes and connected via inserting and folding of flat golden wires (Fig. 1). The following technique has been used before filling the eyes: the relief was formed using repoussé (free hand forging) and then the contours were defined by punching, through chiselling on the side of the face, where this technique left clear marks of the tool. The eyebrows were defined by means of repoussé and chiselling, but these were both crafted from the back side. The lips were crafted with a technique very similar to that used for the eyes - their relief crafted from the back side, while the contours were defined from the front. Particularly aesthetically pleasing and interesting from the standpoint of its crafting is the bee, placed on the forehead right above the nose. The contours on the side of the face are clearly formed (Fig. 2). While it is possible that this part was crafted using a technique similar to the one used for the eyes and lips, we cannot rule out the possibility that a mould or a press was used. It is clearly visible that the chiselled lines along the wings have been crafted from the back. Similarly, we cannot rule out the possibility that moulds were used in the crafting of the decorative ornaments - a meander-shaped and a two linked number-eights-shaped one. A clear pattern of repetition of every fifth element emerges. We can also infer that the mould was placed at the back of the mask. It is clear that at one point the mould was dislocated to the upper left corner, next to the linked number-eights. This

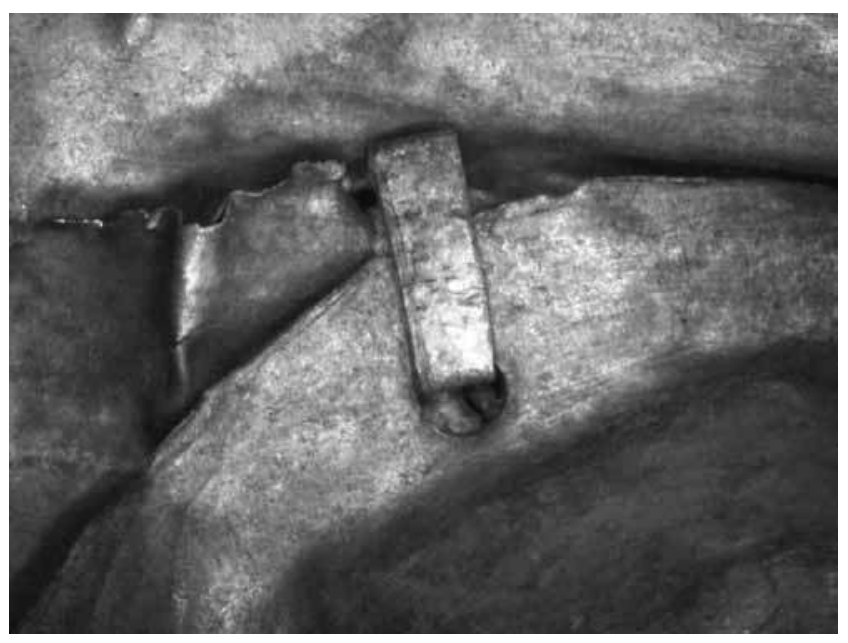

Figure 1: Fitting of the nose with a flat gold band. Figure 1 : Ajustement du nez avec une bande d'or plate.

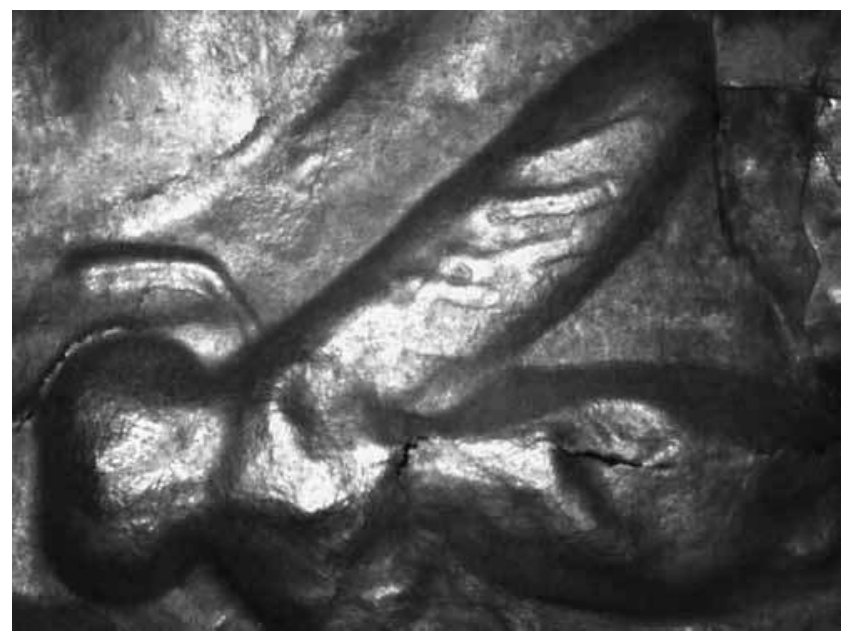

Figure 2: A detail of the bee on the forehead.

Figure 2: Détail de l'abeille sur le front.

is clearly suggested by the surface of the object, which was visibly flattened out and then a relief was formed once again (Fig. 3). The decorative points have been crafted from the back side of the mask.

Hand: Similar to the mask, the hand was most probably also initially cut in the respective shape. Subsequently, its anatomic elements were marked off, namely the position of the phalanges and the nails. The main content of the phalange was crafted from the back side and subsequently completed from the front. The nails were crafted by means of a series of dots from the back. In places, we can see the line which served to guide the crafting of the dots by punching. At the base of the hand, Pavlina Ilieva noticed a figure which had not been described by researchers so

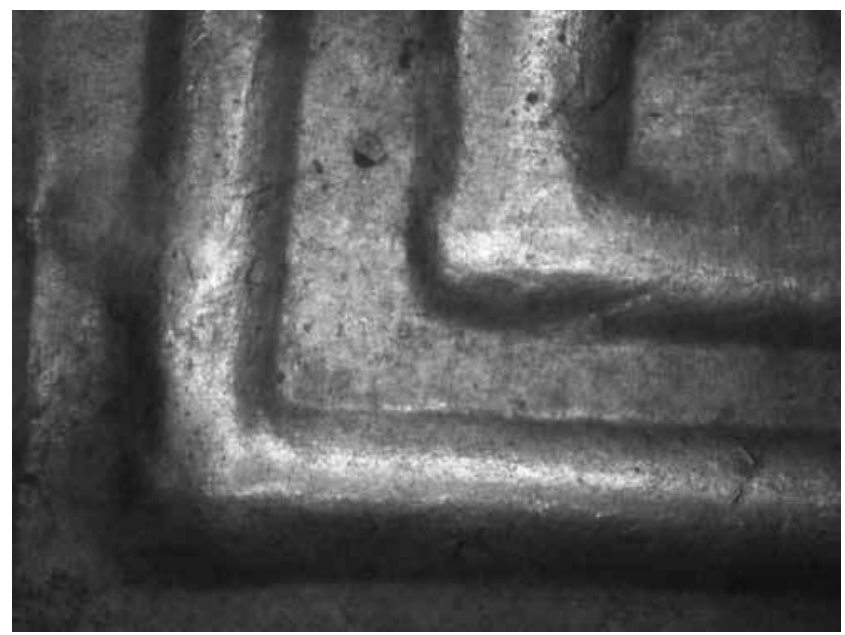

Figure 3: Distinct decoration outlines on the outside.

Figure 3 : Les décorations du contour sur le côté extérieur. 


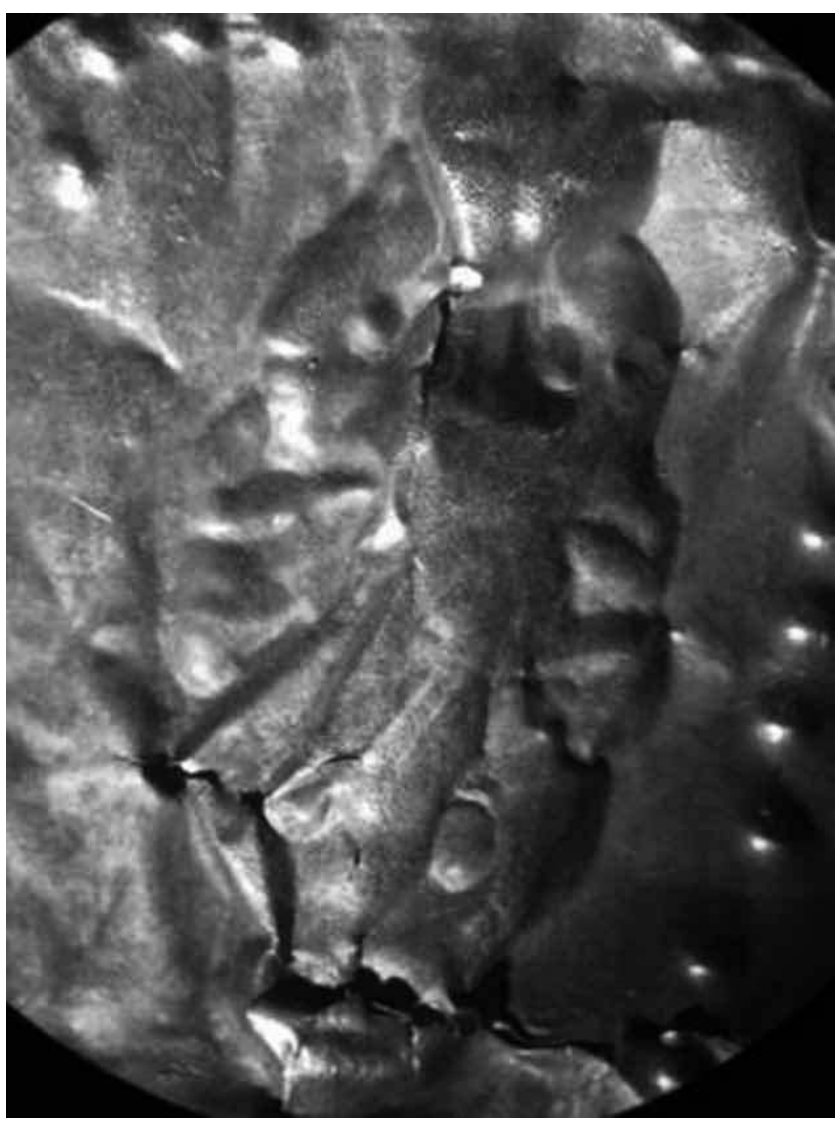

Figure 4: (See colour plate) The figure on the hand. Figure 4 : (Voir planche couleur) La figure sur la main.

far (Fig. 4). It has been crafted mainly from the back side of the hand. The decorative ornament of linked numbereights has been crafted in a way that is identical with that used for the mask.

\begin{tabular}{|c|c|c|c|c|c|}
\hline Inv n $^{\circ}$ & & $\mathrm{Au} \%$ & $\mathrm{Ag} \%$ & $\mathrm{Cu} \%$ & $\mathrm{Fe} \%$ \\
\hline 6859 & Golden mask & 58,9 & 38,2 & 0,7 & 0,8 \\
\hline 6861 & Golden hand & 57,9 & 40,4 & 0,7 & - \\
\hline 6862 & Golden ring & 69,7 & 27,8 & - & - \\
\hline 6885 & Golden appliqué & 62,7 & 25,4 & 0,8 & 4,4 \\
\hline
\end{tabular}

Table 1: Results of the EDX analysis of the gold alloys of the four studied objects.

Tableau 1: Résultat de l'analyse EDS des alliages d'or des quatre objets étudiés.

This preliminary study is part of a more extensive project which will allow a more comprehensive investigation of the gold objects from the Necropolis of Trebeniste. Keeping in mind that the objects from this necropolis are hosted in the above-mentioned three countries, this study corresponds to

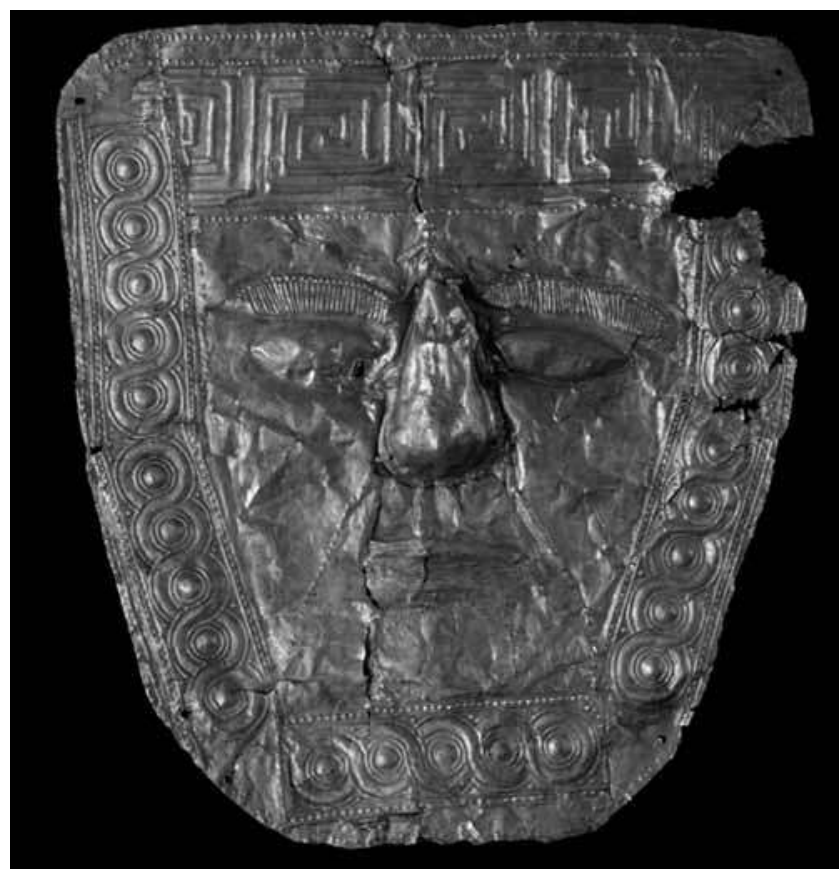

Figure 5: (See colour plate) The golden mask Inv. n 6859. Figure 5: (Voir planche couleur) Le masque d'or, réference dinventaire 6859.

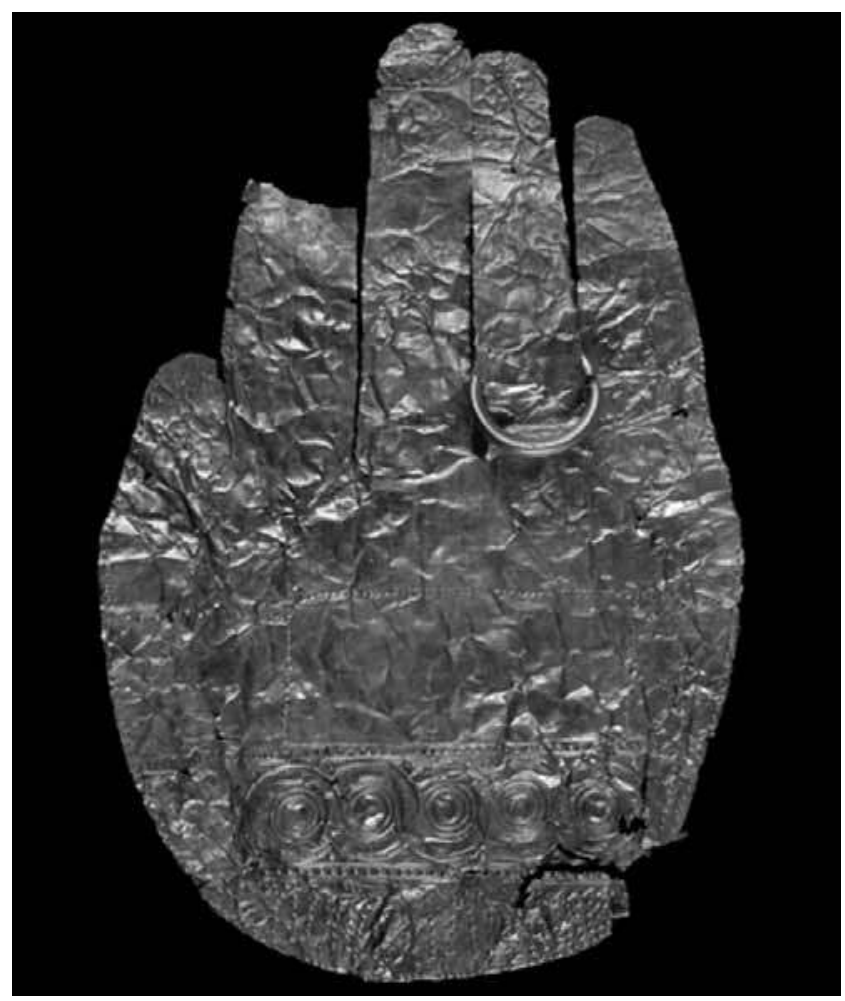

Figure 6: (See colour plate) Golden hand with ring Inv. $n^{\circ} 6861$ and Inv. $n^{\circ} 6862$.

Figure 6: (Voir planche couleur) La main en or avec une bague, référence d'inventaire 6861 et 6862. 
the presentation of preliminary results on the objects currently located in Bulgaria.

The aim of this work was to describe the crafting techniques and to determine the composition of the gold alloys in order to be able to use these first results as a basis for further study and for comparison. If a semi-quantitative analysis is not sufficient for drawing final conclusions on the gold objects from the Necropolis of Trebeniste, these first results nevertheless open up paths for future discussion.

\section{References}

Filov, B.D. and SchкоRPIL, K., 1927. Die archaische Nekropole von Trebenischte am Ochridasee. Berlin and Leipzig, de Gruyter.

Popovic, L.B., 1994. Collection of Greek Antiquities. Belgrade, National Museum Belgrade.

STIBвE, C.M., 1994. Laconian drinking vessels and other open shapes. Laconian black-glazed pottery, Part II. Amsterdam, Allard Pearson Museum.

Vulic, N., 1933. Neue Gräber bei Trebenischte, Archäologischer Anzeiger: 459-482. 
